\title{
Research of low frequency components of a magnetron oscillator spectrum
}

\author{
I. Moshchenko, O. Nikitenko, Chen Xin
}

Kharkiv National University of Radio Electronics, Nauky Ave., 14, 61166, Kharkiv, Ukraine

nikonxipe@gmail.com

\section{Abstract}

In this article the resonant properties of the plant for the investigation of Ku-band magnetrons' operation in the lowfrequency domain from $100 \mathrm{kHz}$ to $35 \mathrm{MHz}$ were experimentally investigated.

Improving the electronic devices' quality is an important task for Ukrainian scientists. It will increase the duration and reliability of sophisticated equipment based on electronic devices, as well as improve the production economic efficiency in the electronics industry.

The most common M-type device, the magnetron, was selected as the studied object. Low-frequency oscillation modes were influenced to the magnetrons' output spectrum quality. Theses modes can occur in the device itself, as well as in the power supply circuits or be induced from the ether. It is hypothesized that spurious oscillations which may impair the electronic devices output spectrum quality, in particular magnetrons, will be amplified at frequencies which the resonances in the device, the supply circuits, and the system as a whole are observed. The experimental study is aimed to determine the frequency domain of the possible occurrence of these spurious oscillations.

The measuring plant for magnetron research consists of a magnetron, a wave type transducer, an absorbent power meter, and a spectrum analyzer. The total error of this setup does not exceed $\pm 4 \mathrm{~dB}$.

The resonant properties study of this plant in the low-frequency domain was performed according to the classical scheme of the resonant properties study of oscillating circuits. The total relative error of resonance properties measurements did not exceed $\pm 8 \%$.

As a result of research, it was discovered a pronounced resonant peak of the magnetron supply circuits in the $30 \mathrm{MHz}$ band, magnetron filament circuits have a pronounced resonant peak in the $20 \mathrm{MHz}$ band, the magnetron has two pronounced peaks in the 5 and $20 \mathrm{MHz}$ band and two peaks in the 15 and $35 \mathrm{MHz}$ band, the system as a whole has two pronounced peaks in the 10 and $30 \mathrm{MHz}$ band.

Keywords: quality; electronic device; magnetron; amplitude; resonance.

\section{Introduction}

In the context of the rapid development of electronic devices and the continuous industry expansion the quality improvement is of particular importance, both to ensure the duration and reliability of the operation of sophisticated electronic devices, and to increase rapidly the economic efficiency of production in the electronics industry. Therefore, the quality improvement, operation duration and reliability of electronic devices are constantly given special attention [1].

The most important conditions for improving the electronic devices' quality, the duration and reliability of their operation are the standardization of general requirements for the electronic devices (ED) quality assurance, the study and standardization of the various factors parameters influencing on the devices, and the creation of appropriate test methods.

The electronic devices' quality is the set of electronic devices properties that determine their ability to perform specified functions under certain operating conditions.

\section{Analysis of recent research and publications}

These properties are characterized by the following indicators: the electronic devices' mission, their reliability, adaptability, operation safety, service convenience, transportability, etc., as well as the properties determined by the ergonomic, aesthetic and environmental properties of the device, the degree of standard and unified products in it. 
Depending on the type, design and operating conditions of the ED, some indicators may be missing. The list of required indicators for certain devices types is set out in the relevant regulatory documents.

The electronic devices' quality control includes input inspection, technological process accuracy inspection and acceptance inspection. Input inspection is carried out to ensure the electron devices' production by raw materials and semi-finished products that meet the requirements of regulatory and technical documentation for such devices manufacture. The results of the technological processes accuracy inspection are used to purposefully regulate the process itself. This inspection type is subjected to both technological operations and devices or devices that produce as an operations result; such inspection is also called operational. During the operational inspection the reasons are identified that lead to the violation of the technological operations accuracy, the limits of regulation of the technological process parameters are determined. Ready electron devices are subject to acceptance inspection. Based on the results of acceptance inspection, the possibility of industrial production of these devices is decided. Such inspection includes qualifying acceptance, periodic electron devices' tests, as well as durability, safety and (if necessary) type tests. If the test results are unsatisfactory, the defects' causes are analyzed and remedial measures are taken.

In the electronic industry of Ukraine, the electronic devices' quality management is carried out by improving the quality of both raw materials, semi-finished products and components, and the equipment production and work culture. The set of controls and management facilities and their connections, which ensure the industrial release of the desired quality ED in a timely manner with minimal material cost, is called the quality management system [2]. Electronic devices quality management involves the quality planning (forecasting, normalization), its accounting and control, analysis and estimation, the decision production to perform planned tasks.

Electronic device quality planning involves ensuring that quality assurance is fulfilled through the development of scientifically based tasks to improve (or maintain the achieved level) quality based on the best use of available resources, and the implementation of organizational measures, research and development activities.

Consideration covers the collection, accumulation and information processing about the actual quality level of electronic devices and the factors that affect it at the stages of development, production and electronic devices operation, as well as the implementation of the planned measures to ensure the assigned tasks. Inspection consists of checking that the results meet the intended standards or requirements. Assessment of the achieved level of electronic devices quality and detection of actual values deviations of quality indicators from the planned ones allow to evaluate more correctly the quality work of the industries, the team and individual performers. Solutions aimed at eliminating the detected deviations in the electronic devices quality, which require the obligatory development of measures to ensure these solutions implementation and the conditions to stimulate the production, teams and individual workers to improve the quality of the products they produce.

In addition to the factors discussed earlier [3, 4], the magnetrons output spectrum quality is influenced by the low-frequency oscillation modes which can occur in the device itself, as well as in the power circuits or be induced from the ether.

Thus, it is relevant to determine the frequency domains of possible occurrence of spurious oscillations, which will impair the output spectrum quality of the electron devices, in particular the most common M-type device - the magnetron.

It is suggested that spurious oscillations can be amplified at frequencies where resonances in the device, supply circuits, and the system as a whole are observed.

Thus this work purpose is experimental investigation of amplitude-frequency resonance magnetron performances, circuit supply and whole system in low frequency domain.

\section{Experimental plant}

No theoretical studies of the M-type devices behavior in the low-frequency domain have been performed.

Due to the fact that the magnetron power supplies have various constructive and schematic embodiments, theoretical studies on this matter do not seem possible.

The results of such circuits experimental studies are considered here because of their such system theoretical description is impossible.

An industrial $\mathrm{Ku}$-band magnetron was selected for a study. In addition, measurements were made in the such devices power circuits and in the whole system.

The experimental studies were performed on the plant according to the scheme shown in Fig. 1. Unfortunately, for each specific this scheme embodiment (Fig. 1) such studies need to be repeated.

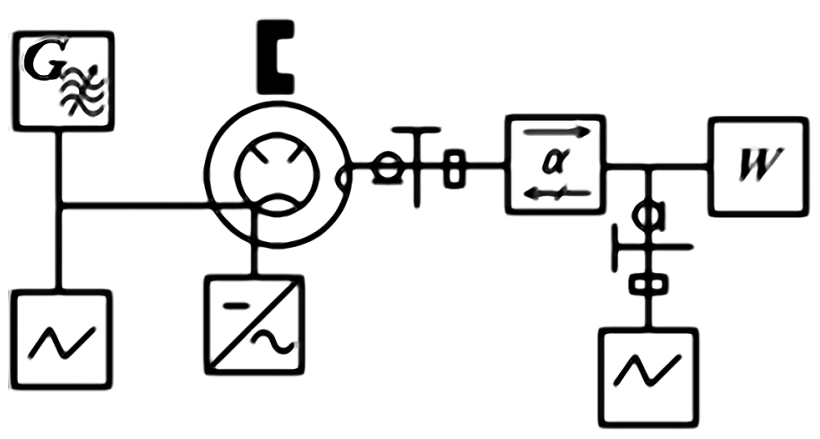

Fig. 1. Functional diagram of the experimental plant: 1 Standard signal generator; 2 -Oscilloscope; 3 - Magnetron; 4 - Power supply; 5 - Coaxial-waveguide adapter; 6 - Valve; 7 - Wattmeter; 8 - Spectrum analyzer

The measuring system contains a standard signal generator AFG-3051 with absolute error in setting the frequency $\pm 10^{-6} \mathrm{~Hz}$, oscilloscope GDS-3000, which 


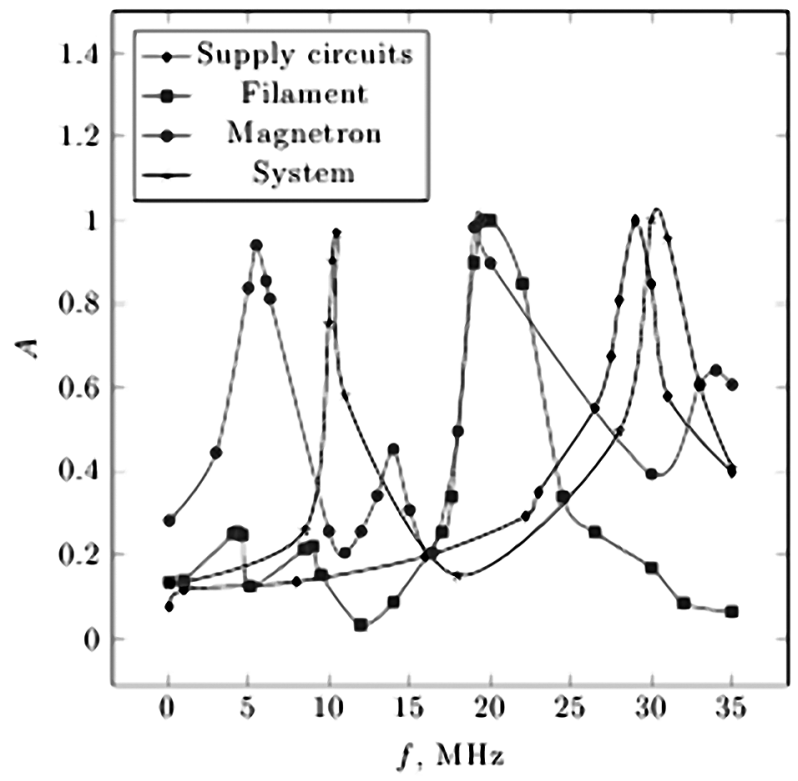

Fig. 2. Performances relative amplitude (A) vs frequency (f)

allows to measure the signal amplitude with a relative error $\pm 2 \%$, the magnetron power supply, the valve, the spectrum analyzer $\mathrm{C} 4-27$, the wattmeter.

\section{Results of the experimental investigation}

The procedure is as follows: to the object being investigated (device, power circuits, and system as a whole), the standard signal generator AFG-3051 provides a calibrated signal in the frequency band $100 \mathrm{kHz}-35 \mathrm{MHz}$ with a rms amplitude $1 \mathrm{~V}$.

Using the GDS-3000 oscilloscope, the signal passed through the object being examined was observed and measured.

The measurement results are shown in Fig. 2.
The y-axis in the Figure (Fig. 2) shows the amplitude relative to the resonance amplitude.

Fig. 2 shows that the magnetron supply circuits have a pronounced resonance peak in the $30 \mathrm{MHz}$ band.

The magnetron filament circuits have a pronounced resonance peak in the $20 \mathrm{MHz}$ band.

In fact, the magnetron has two pronounced peaks in the 5 and $20 \mathrm{MHz}$ band and two much smaller amplitude peaks in the 15 and $35 \mathrm{MHz}$ band.

The system as a whole has two pronounced peaks in the 10 and $30 \mathrm{MHz}$ band.

\section{Conclusion}

Experimental studies of high-voltage power circuits on the part of the connector separately from the device, and the system on "cold measurements" revealed spurious resonant modes, which are located in the $0.1-35 \mathrm{MHz}$ frequency domain. Spectral power, measured in the same range on "hot measurements" through the cathode junction, has a distribution that repeats by the form the output circuits amplitude-frequency response of the devices on the cathode input.

Undoubtedly, the power circuits resonances will create low-frequency modulation of the anode voltage, which may result in lateral components and combining components, which in turn leads to a deterioration in the magnetron output quality.

It is clear that appropriate measures must be taken to attenuate and suppress the spurious resonances in the power circuits.

Any problems analysis related to the identification of the noise causes in M-type devices requires further consideration of additional signals in the magnetron output spectrum.

\title{
Дослідження низькочастотних складових спектра магнетронного генератора
}

\author{
І.О. Мощенко, О.М. Нікітенко, Чень Сінь
}

Харківський національний університет радіоелектроніки, пр. Науки, 14, 61166, Харків, Україна nikonxipe@gmail.com

\section{Анотація}

У статті експериментально досліджено резонансні властивості установки для дослідження роботи магнетронів двосантиметрового діапазону довжин хвиль у низькочастотному діапазоні від 100 кГц до 35 МГц.

Поліпшення якості електронних приладів $є$ важливим завданням для науковців України, оскільки воно забезпечить підвищення тривалості та надійності функціонування складної апаратури на базі електронних приладів, а також сприятиме підвищенню економічної ефективності виробництва в електронній промисловості.

Як об'єкт дослідження було обрано найбільш розповсюджений прилад М-типу - магнетрон. На якість вихідного спектра магнетронів впливають низькочастотні моди коливань, які можуть виникати як у самому приладі, так і в ланцюгах живлення або наводитися з етеру. Висунуто гіпотезу, що паразитні коливання, які можуть погіршувати якість вихідного спектра електронних приладів, зокрема магнетронів, будуть підсилюватися на частотах, за 
яких спостерігаються резонанси у приладі, ланцюгах живлення і системі в цілому. Експериментальне дослідження спрямовано на визначення частотних діапазонів можливого виникнення цих паразитних коливань.

Вимірювальна установка для дослідження роботи магнетронів складається з магнетрона, перетворювача типів хвиль, ватметра поглинаючої потужності та аналізатора спектра. Загальна похибка цієї установки не перевищує 4 дБ.

Дослідження резонансних властивостей цієї установки у низькочастотному діапазоні довжин хвиль відбувалося за класичною схемою дослідження резонансних властивостей коливальних контурів. Загальна відносна похибка вимірювань резонансних властивостей не перевищувала $\pm 8 \%$.

У результаті проведення досліджень виявлено яскраво виражений резонансний пік ланцюгів живлення магнетрона в районі 30 МГц, ланцюги живлення розжарення магнетрона мають яскраво виражений резонансний пік у районі 20 МГц, магнетрон має два яскраво виражених піки в районі 5 і 20 МГц та два піки значно меншої амплітуди в районі 15 і 35 МГц, система в цілому має два яскраво виражених піки в районі 10 і 30 МГц.

Ключові слова: якість; електронні прилади; магнетрон; амплітуда; резонанс.

\title{
Исследование низкочастотных составляющих спектра магнетронного генератора
}

\author{
И.А. Мощенко, О.М. Никитенко, Чень Синь
}

Харьковский национальный университет радиоэлектроники, пр. Науки, 14, 61166, Харьков, Украина nikonxipe@gmail.com

\section{Аннотация}

В статье экспериментально исследованы резонансные свойства установки для исследования магнетронов двухсантиметрового диапазона длин волн в низкочастотном диапазоне от 100 кГц до 35 МГц.

В качестве объекта исследования выбран наиболее распространенный прибор М-типа - магнетрон. На качество выходного спектра магнетронов влияют низкочастотные моды колебаний, которые могут возникать как в самом приборе, так и в цепях питания или наводиться из эфира. Предполагается, что паразитные колебания, ухудшающие качество выходного спектра электронных приборов, усиливаются на частотах, на которых наблюдаются резонансы в приборе, цепях питания и системе в целом.

Измерительная установка состоит из магнетрона, преобразователя типов волн, ваттметра поглощающей мощности и анализатора спектра. Общая погрешность этой установки не превышает 4 дБ.

Исследование резонансных свойств этой установки в низкочастотном диапазоне длин волн проводилось по классической схеме измерения резонансных свойств колебательных контуров. Общая относительная погрешность измерений не превышала $\pm 8 \%$.

В результате проведения исследований обнаружен ярко выраженный резонансный пик цепей питания магнетрона в районе 30 МГц, цепи питания накала магнетрона имеют ярко выраженный резонансный пик в районе 20 МГц, магнетрон имеет два ярко выраженных пика в районе 5 и 20 МГц и два пика значительно меньшей амплитуды в районе 15 и 35 МГц, система в целом имеет два ярко выраженных пика в районе 10 и 30 МГц.

Ключевые слова: качество; электронные приборы; магнетрон; амплитуда; резонанс.

\section{References}

1. Chekmarjov A.A., Prolejko V.M. Kachestvo, nadezhnost i dolhovechnost elektronnykh priborov [Quality, reliability and durability of electronic devices]. Moscow, Energiya Publ., 1972. 224 p. (in Russian).

2. DSTU ISO 9004:2018. Quality management. Quality of an organization. Guidance to achieve sustained success (ISO 9004:2018, IDT). Kyiv, Derzhstandart Ukrainy, 2018. 44 p. (in Ukrainian).
3. Chen Xin, Nikitenko O.M., Ruzhentsev I.V. Pokaznyky jakosti elektrovakuumnykh system zi skhreshchenymy poljamy [Quality factors of crossed-field electrovacuum systems]. Information Processing Systems, 2011, vol. 6 (96), pp. 72-77 (in Ukrainian).

4. Chen Xin, Nikitenko O.M., Ruzhentsev I. V. Anode system quality factors of crossed-field devices. Electrotechnic and Computer Systems, 2012, no. 05(81), pp. 154-157. 